FACTA UNIVERSITATIS

Series: Visual Arts and Music Vol. 6, N 2, 2020, pp. 83 - 92

https://doi.org/10.22190/FUVAM2002083S

Original scientific paper

\title{
MODERN APPROACHES TO TEACHING SIGHT SINGING AND EAR TRAINING
}

\author{
UDC 784.9:004.42
}

\section{Nico Schüler}

Texas State University, School of Music, USA

\begin{abstract}
Sight singing and ear training are difficult subjects to teach. Over the past decade, however, many new technological tools were developed that support educational endeavors. Several of those tools, SmartMusic, SingSnap, EarTrainer (MusicDictation.app), and YouTube, were used at the beginning college-level aural skills courses to enhance sight singing and ear training instruction, especially in the context of enhancing audiation skills. This article summarizes their use within aural skills courses and present experimental and anecdotal evidence of increased sight singing and ear training skills. More specifically, experimental (test) data as well as anecdotal (essay) evidence showed that (1) students were much higher motivated to complete exercises compared to 'traditional' aural skills exercises, (2) in a shorter period of time, students performed much better than in 'traditional' exercises of at least the same difficulty, (3) the students' audiation abilities increased much more as a result of the exercises, compared to 'traditional' exercises, and (4) students showed a greater increase in solfege proficiency, compared to 'traditional' exercises. The teaching approaches we have discussed also led to a greater independence from in-person instruction.
\end{abstract}

Key words: Audiation, Aural Skills, SmartMusic, SingSnap, MusicDictation.app

\section{INTRODUCTION}

Sight Singing and Ear Training are difficult music subjects to teach, as both are highly dependent on the musical backgrounds of the students and on the cognitive processing of music. Instrumentalists are (often) weak in singing-related exercises, while vocalists are usually weaker in ear training tasks, such as melodic, rhythmic, and harmonic dictation. Most schools / colleges / universities in the USA use solfege to support the aural skills acquisition process. Nevertheless, students are un-motivated, because the style of music does not correspond to their listening habits and because instrumentalists do not think

Received November 2020 / Accepted December 2020

Corresponding author: Nico Schüler

Texas State University, School of Music

E-mail: nico.schuler@txstate.edu 
that singing will enhance their musicianship (among other reasons). On the other hand, vocalists are often unmotivated to complete ear training assignments. This article will discuss several technological tools to overcome the lack of motivation and / or provide additional layers of extrinsic motivation.

\section{AUdiATION AS A FUNDAMENTAL SKILL}

"Audiation" of music entails the recollection of previously heard music, the aural prediction (anticipation) of music, and the creation or improvisation of music. Audiation includes the processing of music that is not sounding at the moment (although one can also audiate while listening to music). To be able to audiate music, a student must have heard and understood the music. To aurally recall and process music is the procedure of audiating music that one has previously heard. The aural prediction of music is the audiation of music that we anticipate. Finally, to aurally conceive music is the audiation of music that one creates or improvises.

Audiation is a central category in Music Learning Theory (Brink 1980, Gordon 1989). In Aural Skills courses, the development of audiation skills is most important. Edwin Gordon, the "father" of Music Learning Theory, identified seven types of audiation:

(1) Listening to Music,

(2) Reading Music (silently or in performance),

(3) Writing Music from Dictation,

(4) Recalling Music (silently or in performance),

(5) Writing Music from Recall,

(6) Creating or Improvising Music (silently or in performance), and

(7) Writing Music as it is Created or Improvised.

Students need to practice all these types of audiation. Types (3), (5), and (7) are written applications of types (1), (4), and (6). However, audiation is being done in stages, which may overlap and include, among others, the organization of perceived music into meaningful patterns, the comparing of those patterns with other currently heard patterns, the comparing of those patterns with previously heard music, and the prediction of music.

Singing on letter names (as opposed to movable-do solfege) requires the knowledge of notation. However, music cognition research shows that emphasizing notation-based teaching before acquiring a high degree of audiation skills is a serious violation of the music learning sequence. Since many university students in the USA are limited in their audiation skills, we ask students to mainly use movable-do solfege. Specific tonal patterns (e.g., do-re-mi) are associated with the same syllables in all keys, while using letter names or fixed-do requires fifteen different verbal associations to "cover" all different keys. Finally, movable-do (dobased minor) emphasizes the function of pitches and tonal patters, whereas letter names do not; understanding the function of pitches and tonal patterns is most important for audiation processes. Therefore, most colleges and universities in the USA ask students to sing with movable-do (do-based minor) solfege, instead of letter names. 


\section{KARAOKE EXERCISES AND SMARTMUSIC TO ENHANCE AUDIATION SKILLS FOR (SIGHT-) SINGING}

With the goal of increasing audiation and (sight-) singing abilities, and with the goal of internalizing solfege, beginning aural skills (college) students were asked to use a free online karaoke web-site (www.singsnap.com) to pick any song, 'figure out' the solfege (by any means), practice singing the song on solfege, and record it on that online karaoke website. All recordings were played in class and evaluated by all students as well as the instructor. Later, students were also asked to write a brief essay about their 'karaoke experience'. For another class, students were paired up, as most students had never used solfege before. The goal was that the partner learning experience would boost their solfege singing skills and confidence. Evaluations by the teacher, other students, and themselves were collected, as well. These karaoke exercises also allowed students to choose music they like, which increased their motivation dramatically.

'Real' sight singing is difficult to practice, as it is only the first time that a student sings a melody and that melody is 'new'. Students may correct their work and advance in sight singing only if they receive feedback on their 'real' sight singing exercises; traditionally, that is almost impossible outside of class, as students either practice alone or with a peer, and peers may not provide adequate feedback. To alleviate this problem, the interactive music software SmartMusic (www.smartmusic.com) has been used by the author's students to practice 'real' (first-time) sight singing: SmartMusic provides visual and audio feedback on the students' performance. On the other hand, SmartMusic also allows for 'repertoire building' by asking students to practice certain melodies to perfection.

For both approaches of using technology (SingSnap and SmartMusic), experimental (test) data as well as anecdotal (essay) evidence showed that (1) students were much higher motivated to complete exercises than 'traditional' singing exercises, (2) in a shorter period of time, students performed much better than in 'traditional' singing exercises of at least the same difficulty, (3) the students' audiation abilities increased much more as a result of the exercises, compared to 'traditional' singing exercises, and (4) students showed a greater increase in solfege proficiency, compared to 'traditional' singing exercises.

More specifically, the following three quotes from students show anecdotal evidence of the effectiveness of using SingSnap (While the author of this article has been using SingSnap continuously since 2008 with a total of more than one hundred students, these specific quotes, representative of the entire sample, are from students from Spring 2008. See also Weaver 2008).

"In class, we were introduced to www.singsnap.com. The assignment on the Addams Family was a tough one, because having to know the solfege was a little tricky. I think it was helpful in the sense that we had to sing the song in just pure solfege syllables, because it made us think on the different ways we can use solfege, and not only in class by singing scales." (Student A)

"After my first listen of Eight Days a Week I realized that this was going to take much more time than I thought. The strange thing was that I actually wanted to figure this song out on solfege. I thought at first that this was going to be pointless and boring, but then I realized I could apply some of the things that I had learned earlier in the year to real world music. This made me very happy. I felt like my education was in a way being validated. Once I figured out the song on solfege I understood the song in a whole new way." (Student B) 
"The karaoke assignment that was given this semester actually turned out rather well. I thought that it was an ingenious way to blend aural learning with popular music and that extra bit of fun. I must admit that, at first, I was weary about what this assignment would turn out to be; would it be only pre-approved songs, would we only be allowed to learn them a certain way, but after it was said and done I found this assignment to be a great learning tool. In requiring at least two songs done only in solfege, I believe that this helps students to realize the inner-workings of the melodies and verses of the songs instead of students thinking the tune and words are as far as the song goes." (Student C)

The effectiveness of SmartMusic was measured by comparing the sight singing ability by assigning the same melody before and after a 4 -week practice period:

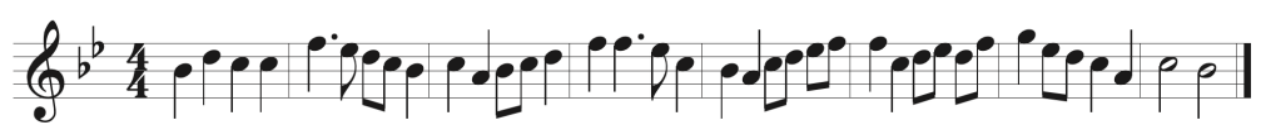

Fig. 1 Pre - and Post-Test Sight Singing Melody

During the practice period, students were assigned 15 melodies each week, which students were asked to practice to perfection (100\% correct) before submitting each melody in SmartMusic (This experiment took place during the month of September 2020 semester with 23 first-semester music Bachelor students: 6 female and 17 male. Gender differences in the performance were not observed). That practice to perfection enabled students to gain 'real' sight-singing skills, as shown in the pre - and post-test results for the sight-singing melody shown earlier:

Table 1 Pre - and Post-Test Results for Melodic Sight Singing

\begin{tabular}{|l|r|r|}
\hline & 29-Aug & 26-Sep \\
\hline Student1 & 16 & 76 \\
\hline Student2 & 76 & 84 \\
\hline Student3 & 19 & 90 \\
\hline Student4 & 64 & 100 \\
\hline Student5 & 26 & \\
\hline Student6 & 36 & 51 \\
\hline Student7 & 58 & 91 \\
\hline Student8 & 0 & 57 \\
\hline Student9 & 0 & 90 \\
\hline Student10 & 21 & 62 \\
\hline Student11 & 22 & 64 \\
\hline Student12 & 50 & 82 \\
\hline Student13 & 16 & 61 \\
\hline Student14 & 58 & 79 \\
\hline Student15 & 100 & 100 \\
\hline Student16 & 26 & \\
\hline Student17 & 60 & 88 \\
\hline Student18 & 81 & 98 \\
\hline Student19 & & 80 \\
\hline Student20 & 10 & 38 \\
\hline Student21 & 56 & 85 \\
\hline Student22 & 38 & 81 \\
\hline Student23 & 44 & 81 \\
\hline AVERAGE & 39.8636364 & 78 \\
\hline t-test & $1.9918 E-06$ & 0.000002 \\
\hline
\end{tabular}


The grading was based to two-thirds on pitch and one-third on melody. The pre-test average score was $39.9 \%$, while the post-test average score was $78 \%$. The t-test showed that the difference between pre - and post-test results were highly significant. The following is one example of improvement over the 4-week period; the green note heads indicate correct pitches, while red note heads indicate incorrect pitches; horizontally shifted note heads indicate rhythmic errors:

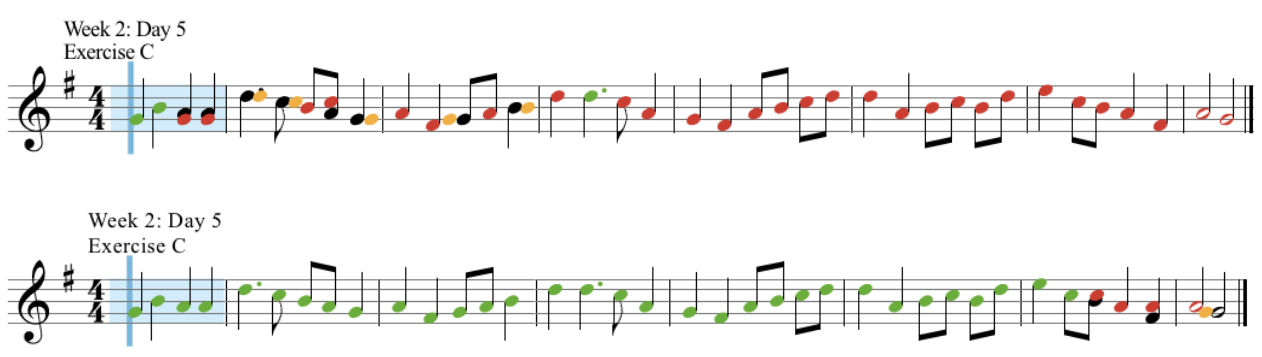

Fig. 2 A Student's Pre - and Post-Test Performance on Sight Singing

One might ask if the students remembered the melody from the pre-test, when taking the post-test. Both 'tests' were actually given as a regular sight-singing melody, and students were not aware that it was a 'test'. When later asked whether they recognized the melody, all of the students said they did not. Regardless, even when practicing the same melody twice (or more times) in a row, the score usually does not increase that quickly.

\section{JERSILD PROGRESSIONS, Sing \& Play EXERCISES, AND THE USE OF YouTubE}

In addition to working with SingSnap and SmartMusic, students are required to practice and video-record Jersild progressions (Rogers 1996) as well as Sing-and-Plays. Jersild progression are tonal progressions, one in each major and minor key, that consist of the most common two-note patterns, for example:


Fig. 3 The C Major Jersild Progression (Rogers 1996) 
A Sing-and-Play is a piece of music that must be sung to a piano accompaniment. A student sings and plays piano at the same time, for example:

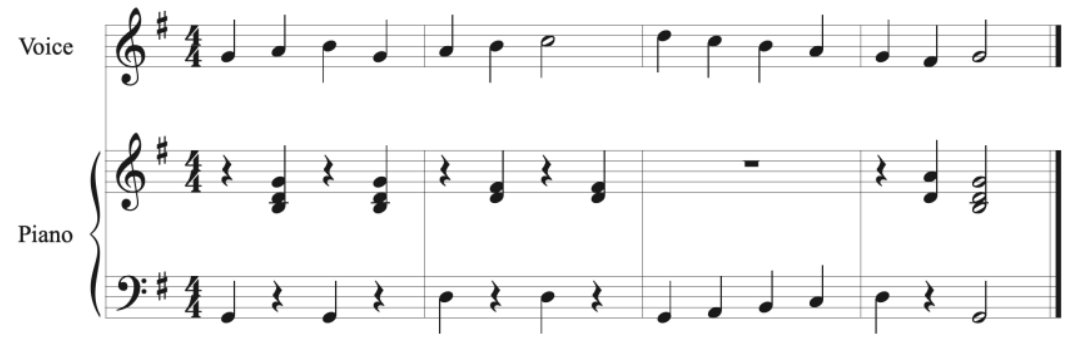

Fig. 4 Example of a Sing \& Play

The idea of video-recording Jersild progressions as well as Sing-and-Play exercises ensures that students practice them to perfection, before posting them to an 'unlisted' YouTube Playlist that the instructor has access to. Although no empirical data was collected before YouTube was used (students had to prepare them and perform them in class, which meant that not all students could also play them in class, because of the limited class time and large class size [20 students on average]), students now seem to be much better prepared, are more motivated, and complete their assignments on a more regular basis.

\section{DEVELOPING AUdIATION \& TRANSCRIPTION SKILLS: EXERCISE PROCEDURE FOR ‘UNKNOWN’ SONGS - WITH ADDED SINGSNAP COMPONENT}

In most of the cases, problems in melodic dictation are a result of an un - or underdeveloped musical memory and under-developed audiation skills. Students are unable to remember and / or audiate music sufficiently. The following exercise is directed at developing musical memory and audiation skills while transcribing melodies. - The exercise is given with the following directions to students:

(1) Listen carefully to the 'unknown' song ONCE and try to remember as much of the main melody as possible.

(2) Sing the melody back on a neutral syllable (not solfege!) - sing as much as you can remember of it.

(3) Repeat steps (1) and (2) until you can sing the entire melody back on a neutral syllable.

(4) One or two days later, make sure you can still remember the melody and sing it on a neutral syllable. If you do not, repeat steps (1) to (3).

(5) One or two days later, sing the melody on solfege. This may take several (or quite a few) trials, as it is not easy to figure out the solfege syllables.

(6) One or two days later, make sure you can still remember the melody and sing it on solfege. If not, repeat steps (1) to (5).

(7) Record the song, using solfege, on SingSnap.com

(8) Write down the melody in three different keys. The keys may be chosen by the instructor or by the student. 


\section{USING EAR TRAINING SOFTWARE}

For ear training, software such as EarMaster Pro (www.earmaster.com), MacGamut (www.macgamut.com), Practica Musica (www.ars-nova.com/practica7.html), or Auralia (www.risingsoftware.com/auralia) have been in use for more than two decades, and their design has significantly improved over the years. Free ear training websites are also available, such as www.teoria.com. Ear training software allows students to practice at home, while class time can be spent on how to train students' listening skills. In addition, promising new software was developed in 2020: The EarTrainer at www.MusicDictation.app allows instructors to create melodic, rhythmic, and harmonic dictations and assign them to students. Once completed, assignments are automatically graded and scores are saved in a gradebook. It is much more user-friendly than the customization options in older software packages. The instructor can either enter ear training assignments or upload them from an XML file (which can be saved from most notation programs). The online program can generate the recordings, or the instructor may upload a recording of the assignments.

In addition to ear training software, students are also assigned recordings of songs that students need to transcribe in three different keys. None of the musical information is given to students, so students have to identify all musical parameters by themselves. This provides a holistic approach with 'real world' music.

\section{FINAL REMARKS}

Music technology can help enhancing the students' sight singing and dictation skills. This study specifically focused on using the free online software SingSnap (SingSnap.com) and the commercial music software SmartMusic, as well as on using YouTube for students to upload video-recordings of assignments and on the new ear training software EarTrainer at www.MusicDictation.app. Using all of them allows instructors to save class time and or to pursue remote instruction, and students gained aural skills faster and with greater accuracy.

Last but not least, a sample assignment schedule shall be given here from a firstsemester aural skills course:

Table 2 Sample Assignment Schedule for First-Semester Aural Skills

\begin{tabular}{lll}
\hline & Ear Training Assignments & Sight Singing Assignments \\
\hline Week 1 & Monday: [first day of class] & Monday: [first day of class] \\
& Wednesday: Set Up musicdictation.app & Wednesday: The Sound of Music - Do Re \\
& Friday: practice on teoria.com & Mi Song; Set up SmartMusic \\
& & Friday: SmartMusic \\
\hline Week 2 & $\begin{array}{l}\text { Monday: Practice Intervals } \\
\text { (theoria.com) }\end{array}$ & Monday: sing intervals ( $\uparrow \downarrow \downarrow$ ) m2, M2, m3, \\
& Wednesday: Song 1 (C, F, G) & M3, P4, P5 \\
& Friday: musicdictation.app & Wriday: SmartMusic \\
& assignments & \\
\hline Week 3 3 Monday: & Monday: \\
& Wednesday: Song 2 (Bb, D, Eb); & Wednesday: SING \& PLAY 2; Jersild C- \\
& $\begin{array}{l}\text { Practice Intervals \& Scales on } \\
\text { teoria.com }\end{array}$ & Major \\
& Friday: musicdictation.app & Friday: SmartMusic \\
assignments & \\
\hline
\end{tabular}




\begin{tabular}{|c|c|c|}
\hline Week 4 & $\begin{array}{l}\text { Monday: Song } 3(\mathrm{~A}, \mathrm{Ab}, \mathrm{E}) \\
\text { Wednesday: Practice Melodic \& } \\
\text { Rhythmic Dictation on teoria.com } \\
\text { Friday: musicdictation.app } \\
\text { assignments }\end{array}$ & $\begin{array}{l}\text { Monday: SING \& PLAY } 3 \\
\text { Wednesday: Jersild a-minor } \\
\text { Friday: SmartMusic }\end{array}$ \\
\hline Week 5 & $\begin{array}{l}\text { Monday: Song } 4(\mathrm{Db}, \mathrm{B}, \mathrm{Gb}) \\
\text { Wednesday: Practice Harmonic } \\
\text { Dictation on teoria.com } \\
\text { Friday: musicdictation.app } \\
\text { assignments }\end{array}$ & $\begin{array}{l}\text { Monday: SING \& PLAY } 4 \\
\text { Wednesday: Jersild G-Major } \\
\text { Friday: SmartMusic }\end{array}$ \\
\hline Week 6 & $\begin{array}{l}\text { Monday: Song } 5(\mathrm{C}, \mathrm{F}, \mathrm{G}) \\
\text { Wednesday: Practice on teoria.com } \\
\text { Friday: musicdictation.app } \\
\text { assignments }\end{array}$ & $\begin{array}{l}\text { Monday: SING \& PLAY } 5 \\
\text { Wednesday: sing intervals ( } \uparrow \text { ) m6, M6, m7, } \\
\text { M7, P8 } \\
\text { Friday: SmartMusic }\end{array}$ \\
\hline Week 7 & $\begin{array}{l}\text { Monday: Song } 6(\mathrm{Bb}, \mathrm{D}, \mathrm{Eb}) \\
\text { Wednesday: Practice on teoria.com } \\
\text { Friday: musicdictation.app } \\
\text { assignments }\end{array}$ & $\begin{array}{l}\text { Monday: SING \& PLAY } 6 \text { (CP p. } 65, \text { w/ } \\
\text { Bass Line 1) } \\
\text { Wednesday: Jersild e-minor } \\
\text { Friday: SmartMusic }\end{array}$ \\
\hline Week 8 & $\begin{array}{l}\text { Monday: Song } 7(\mathrm{~A}, \mathrm{Ab}, \mathrm{E}) \\
\text { Wednesday: Practice on teoria.com } \\
\text { Friday: musicdictation.app } \\
\text { assignments }\end{array}$ & $\begin{array}{l}\text { Monday: SING \& PLAY } 7 \\
\text { Wednesday: review all Jersild progressions } \\
\text { Friday: SmartMusic }\end{array}$ \\
\hline Week 9 & $\begin{array}{l}\text { Monday: Song } 8(\mathrm{Db}, \mathrm{B}, \mathrm{Gb}) \\
\text { Wednesday: Practice on teoria.com } \\
\text { Friday: musicdictation.app } \\
\text { assignments }\end{array}$ & $\begin{array}{l}\text { Monday: SING \& PLAY } 8 \text { (CP p. 66, w/ } \\
\text { Bass Line 1) } \\
\text { Wednesday: sing intervals }(\downarrow) \text { m6, M6, m7, } \\
\text { M7, P8 } \\
\text { Friday: SmartMusic }\end{array}$ \\
\hline $\begin{array}{l}\text { Week } \\
10\end{array}$ & $\begin{array}{l}\text { Monday: Song } 9(\mathrm{C}, \mathrm{F}, \mathrm{G}) \\
\text { Wednesday: Practice on teoria.com } \\
\text { Friday: musicdictation.app } \\
\text { assignments }\end{array}$ & $\begin{array}{l}\text { Monday: SING \& PLAY } 9 \\
\text { Wednesday: review all intervals; Jersild D- } \\
\text { Major } \\
\text { Friday: SmartMusic }\end{array}$ \\
\hline $\begin{array}{l}\text { Week } \\
11\end{array}$ & $\begin{array}{l}\text { Monday: Song } 10 \text { (F\#, C\#, Gb) } \\
\text { Wednesday: Practice on teoria.com } \\
\text { Friday: musicdictation.app } \\
\text { assignments }\end{array}$ & $\begin{array}{l}\text { Monday: SING \& PLAY } 10 \\
\text { Wednesday: Jersild b-minor } \\
\text { Friday: SmartMusic }\end{array}$ \\
\hline $\begin{array}{l}\text { Week } \\
12\end{array}$ & $\begin{array}{l}\text { Monday: Song } 11(\mathrm{Cb}, \mathrm{Db}, \mathrm{B}) \\
\text { Wednesday: Practice on teoria.com } \\
\text { Friday: musicdictation.app } \\
\text { assignments }\end{array}$ & $\begin{array}{l}\text { Monday: SING \& PLAY } 11 \\
\text { Wednesday: Jersild F-Major } \\
\text { Friday: SmartMusic }\end{array}$ \\
\hline $\begin{array}{l}\text { Week } \\
13\end{array}$ & $\begin{array}{l}\text { Monday: Song } 12(\mathrm{E}, \mathrm{Ab}, \mathrm{D}) \\
\text { Wednesday: Practice on teoria.com } \\
\text { Friday: musicdictation.app } \\
\text { assignments }\end{array}$ & $\begin{array}{l}\text { Monday: SING \& PLAY } 12 \\
\text { Wednesday: Jersild d-minor } \\
\text { Friday: SmartMusic }\end{array}$ \\
\hline $\begin{array}{l}\text { Week } \\
14\end{array}$ & $\begin{array}{l}\text { Monday: Song } 13(\mathrm{~A}, \mathrm{~F}, \mathrm{Bb}) \\
\text { Wednesday: Practice on teoria.com } \\
\text { Friday: musicdictation.app } \\
\text { assignments }\end{array}$ & $\begin{array}{l}\text { Monday: SING \& PLAY } 13 \\
\text { Wednesday: review all Jersild progressions } \\
\text { Friday: SmartMusic }\end{array}$ \\
\hline $\begin{array}{l}\text { Week } \\
15\end{array}$ & $\begin{array}{l}\text { Monday: Song } 14(\mathrm{~Eb}, \mathrm{G}, \mathrm{C}) \\
\text { Wednesday: Practice on teoria.com; } \\
\text { musicdictation.app assignments }\end{array}$ & $\begin{array}{l}\text { Monday: review all Jersild progressions } \\
\text { Wednesday: SmartMusic }\end{array}$ \\
\hline
\end{tabular}


Acknowledgement: I would like to gratefully acknowledge the suggestions and contributions by graduate assistants Anne Weaver, Cecilia Kittley, and Renee Rodriguez. I would especially like to thank Anne Weaver for initially making me aware of the karaoke website SingSnap.com. (See also Weaver 2008.)

\section{REFERENCES}

Asmus, E. P., (1994), "Motivation in Music Teaching and Learning", The Quarterly Journal of Music Teaching and Learning 5/4: pp. 5-32.

Azzara, C. D., (1991), "Audiation, Improvisation, and Music Learning Theory", The Quarterly Journal of Music Teaching and Learning II/1-2: pp. 106-109.

Brink, E. R., (1980), A Cognitive Approach to the teaching of aural skills viewed as applied music theory, Doctoral dissertation, Northwestern University.

Brink, E. R., (1983), "A look at E. Gordon's Theories", Council for Research in Music Education Bulletin 75: pp. 1-13.

Buck, M. W., (2008), The Efficacy of SmartMusic ${ }^{\circledR}$ Assessment as a Teaching and Learning Tool, Doctoral dissertation, The University of Southern Mississippi.

Covington, K. R., and C. H. Lord, (1994), "Epistemology and Procedure in Aural Training: In Search of a Unification of Music Cognitive Theory with its Applications", Music Theory Spectrum 16/2: pp. 159-170.

Denski, S. W. (1990). An examination of popular music preferences and functions by the contemporary popular music audiences, Doctoral dissertation, Ohio University.

Droe, K., (2006), "Music Preference and Music Education: A Review of Literature," UPDATE: Applications of Research in Music Education 24: pp. 23-32.

Fetto, J., (2002/2003), "Young Listeners", American Demographics 24: p. 11.

Fung, C. V., (1996), "Musicians' and Non-Musicians' Preferences for World Musics: Relation to Musical Characteristics and Familiarity", Journal of Research in Music Education 44: pp. 60-83.

Gordon, E. E., (1989), "Tonal Syllables: A Comparison of Purposes and Systems", in Walters \& Taggart 1989, pp. 66-71.

Gordon, E. E., (2003). Learning Sequences in Music: Skill, Content, and Patterns. A Music Learning Theory, GIA Publications, Chicago.

Harrington, E. M., (1991), "Rock Music as a Resource in Harmonic, Melodic, and Metric Dictation", College Music Symposium 31: pp. 27-35.

Houlahan, M. B., (1989), A Methodology for Teaching Ear Training, Sight Singing and Harmony at the College Level Based on the Concept of Zoltan Kodaly, Doctoral dissertation, Catholic University of America.

Houlahan, M. B., and Ph. Tacka, (1990), "Sound Thinking: A Suggested Sequence for Teaching Musical Elements for a College Music Theory Course", Journal of Music Theory Pedagogy 4/1: pp. 85-109.

Karas, J. B., (2005), The Effect of Aural and Improvisatory Instruction on Fifth Grade Band Students' Sight Reading Ability, Doctoral dissertation, The University of Nebraska.

Karpinski, G. S., (1990), "A Model for Music Perception and its Implications in Melodic Dictation", Journal of Music Theory Pedagogy 4/2: pp. 191-230.

Karpinski, G. S., (2000). Aural Skills Acquisition: The Development of Listening, Reading, and Performing Skills in College-Level Musicians, Oxford University Press, New York.

Kittley, C., (2009), The Volunteer Choir: Pedagogical Aspects of Sight-Reading in the Church Choir Setting. Master's thesis, Texas State University.

Kleppinger, St. V., (2017), "Practical and Philosophical Reflections Regarding Aural Skills Assessment", Indiana Theory Review 33: pp. 153-182.

Klonoski, E. W., Jr., (1998), "Teaching Pitch Internalization Processes", Journal of Music Theory Pedagogy 12: pp. 81-96.

Lake, W. E., (1993), "Interval and Scale-Degree Strategies in Melodic Perception", Journal of Music Theory Pedagogy 7: pp. 55-67.

Larson, St., (1993), "Scale-Degree Function: A Theory of Expressive Meaning and its Application to Aural Skills Pedagogy", Journal of Music Theory Pedagogy 7: pp. 69-84.

Larson, St., (1995), "Integrated Music Learning and Improvisation: Teaching Musicianship and Theory through 'Menus, Maps, and Models'", College Music Symposium 35: pp. 76-90.

Lee, E., (2007), A Study of the Effect of Computer Assisted Instruction, Previous Music Experience, and Time on the Performance Ability of Beginning Instrumental Music Students, Doctoral dissertation, The University of Nebraska.

Potter, G. M., (1990), "Identifying Successful Dictation Strategies", Journal of Music Theory Pedagogy 4/1: pp. 63-71.

Prytuluk, N. A., (2000), Sound-to-Symbol Pedagogical Practices in Music and Language. Doctoral dissertation, University of Alberta. 
Reznicow, J., (2009), The Effect SmartMusic has on Improving an Individual's Intonation and Rhythmic Accuracy, Master's thesis, Coe College.

Rentfrow, P. J., and S. D. Gosling, (2003), "The Do Re Mi's of Everyday Life: The Structure and Personality Correlates of Music Preferences", Journal of Personality and Social Psychology 84/6: pp. 1236-1256.

Reynolds, G., (2000), "Relationships Between musical Aptitude and Musical Preference Among High School Students", Contributions to Music Education 27/1: pp. 78-90.

Rodriguez, A. R., (2009), A Descriptive Study of the Integration of Music Theory Instruction in Selected Instrumental Music Programs in Texas, Master's thesis, Texas State University.

Rogers, M., (1983), "Beyond Intervals: The Teaching of Tonal Hearing", Indiana Theory Review VI/3: pp. 18-34.

Rogers, M., (1983), Teaching Approaches in Music Theory: An Overview of Pedagogical Philosophies, Southern Illinois University Press, Carbondale.

Rogers, M., (1996), "The Jersild Approach: A Sightsinging Method from Denmark", College Music Symposium 36: pp. 149-161.

Schüler, N., (2013), "Technology as a Tool to Enhance Sight Singing Education", Music and Technologies, ed. by D. Kucinskas and St. Davismoon, Cambridge Scholars, Newcastle upon Tyne, pp. 73-81.

Sheldon, D. A., S. Reese, and J. Grashel, (1999), "The Effects of Live Accompaniment, Intelligent Digital Accompaniment, and No Accompaniment on Musicians' Performance Quality", Journal of Research in Music Education 47/3: pp. 251-265.

Snapp, D. R., (1997), The Uses and Effectiveness of the Vivace Intelligent Accompanist ${ }^{\circledR}$ System in K-12 Instrumental Music Programs. Doctoral dissertation. University of Northern Colorado.

Tourinho, I., (1998), "Educational Considerations about a Study of Young Students' Musical Preferences and Habits", Dialogue in Instrumental Music Education 22/1: pp. 36-45.

Tseng, S.-M. A., (1996), Solo Accompaniments in Instrumental Music Education: The Impact of the ComputerControlled Civace on Flute Student Practice, Doctoral dissertation, University of Illinois at Urbana-Champaign.

VanHandel, L., (2020), Ed., The Routledge Companion to Music Theory, Routledge, New York.

Walters, D. L., (1989), "Audiation: The Term and the Process", Readings in Music Learning Theory, ed. by D. L. Walters and C. C. Taggart, G.I.A. Publications, Chicago, pp. 3-11.

Weaver, A. C., (2008), Music to Their Ears: The Importance of Familiarity in Learning and Incorporating Popular Music Styles into the College Teaching of Aural Skills. Master's thesis, Texas State University.

Walters, D. L., and C. C. Taggart, (1989), Eds, Readings in Music Learning Theory, G.I.A. Publications, Chicago.

\section{MODERNI PRISTUPI NASTAVI PEVANJA S LISTA I RAZVIJANJA SLUHA}

Pevanje s lista i vežbanje sluha nije lako predavati. Međutim, tokom prošle decenije, razvijeni su mnogi novi tehnološki alati koji pomažu u nastavi. Neki od njih, poput SmartMusic, SingSnap, EarTrainer MusicDictation.app i YouTube, korišćeni su u početnim kursevima na koledžima za unapređivanje nastave pevanja s lista i razvijanja sluha, posebno u kontekstu poboljšanja audiacije, tj. veštine spoznaje zvuka. Ovaj rad sumira njihovo korišćenje u okviru kurseva slušnih veština $i$ predstavlja eksperimentalne i narativne zapise poboljšanog pevanja s lista i razvijanja sluha. Još preciznije, eksperimentalni (test) podaci kao i narativni dokazi (u formi eseja) pokazali su da (1) su studenti, u poređenju sa 'traditiconalnim' vežbama slušnih veština, bili mnogo motivisaniji da urade vežbe, (2) da su studenti u znatno kraćem roku postizali mnogo bolje rezultate nego sa 'traditiconalnim' vežbama približno iste težine, (3) da su se, u poređenju sa 'traditiconalnim' vežbama, veštine audiacije kod studenata znatno unapredile kao rezultat ovih vežbi $i$ (4) da su studenti, u poređenju sa 'traditiconalnim' vežbama, pokazali znatan napredak u pogledu pevanja s lista i unapređenja sluha. Pristupi u nastavi koji se ovde razmatraju, takođe su imali za rezultat $i$ veću samostalnost/nezavisnost u odnosu na nastavu licem u lice.

Ključne reči: audiacija, slušne veštine, SmartMusic, SingSnap, MusicDictation. 